\title{
Complement inhibitors and immunoconglutinins in ulcerative colitis and Crohn's disease
}

\author{
B J POTTER, D J C BROWN, A WATSON, AND D P JEWELL* \\ From The Academic Department of Medicine, Royal Free Hospital, London
}

SUMmaRY The serum concentrations of the complement inactivators CiINH, C3bINA and $\beta_{1 \mathrm{H}}$ have been determined in patients with ulcerative colitis and Crohn's disease and their correlation with $\mathrm{C} 3$ and properdin factor $\mathrm{B}$ examined. The incidence of immunoconglutinins $(1 \mathrm{~K})$ in these patients was investigated. Raised serum concentrations of CīINH and C3bINA have been found in patients with active disease, but no significant alteration was found in serum concentration of $\beta_{1 \mathrm{H}}$. An increasing incidence of positive $1 \mathrm{~K}$ titres was found with increased length of disease history. These results suggest continuing complement activation in these diseases.

Serum concentrations of several complement components are known to be altered in ulcerative colitis and Crohn's disease. C3 and properdin factor B are raised and may show a positive correlation with disease activity and the extent of the inflammation. ${ }^{2}$ Less marked changes have been found for $\mathrm{C}^{2-4}$ and no significant change occurs in the serum concentration of $\mathrm{Cl}_{\mathrm{q}} .{ }^{1}$ These changes can be interpreted as occurring secondary to acute inflammation. However, direct evidence for increased complement consumption has been presented from metabolic studies of purified $\mathrm{Cl}_{\mathrm{q}}$ and $\mathrm{C} 3 .^{56}$ Furthermore, an increased incidence of conversion products of $\mathrm{C} 3$ and properdin factor $B$ has been found. ${ }^{7} 8$

It is not known whether increased complement activation occurs purely as a result of continuing antigen-antibody reactions or whether there is a defective modulation of the complement cascade. The aim of this study, therefore, was to assay the inhibitors of the complement system and to provide additional evidence of continuing complement activation by measuring the titres of serum immunoconglutinins (which are antibodies to activated complement components).

\section{Methods}

PATIENTS

Blood was obtained from 45 patients with ulcerative colitis, 41 patients with Crohn's disease, and 32

*Address for correspondence: Dr D P Jewell, Department of Gastroenterology, John Radcliffe Hospital, Oxford OX3 9DU.

Received for publication 4 August 1980 normal healthy control subjects. Sex and age distribution in each group was similar. Sera from all the controls were collected during the winter period (November to February) and from $85 \%$ of patients with ulcerative colitis and $88 \%$ with Crohn's disease.

Ulcerative colitis and Crohn's disease were diagnosed on standard clinical, radiological, and histological criteria. Disease activity was graded according to the criteria of Truelove and Witts ${ }^{9}$ for ulcerative colitis and de Dombal et al. ${ }^{10}$ for Crohn's disease.

ESTIMATION OF COMPLEMENT COMPONENTS AND INHIBITORS

Sera were separated within two hours of collection. They were stored in aliquots at $-20^{\circ} \mathrm{C}$ until use, when they were rapidly thawed in a water bath at $37^{\circ} \mathrm{C}$. C3 and properdin factor B were estimated by single radial immunodiffusion using Diffugen plates (Searle) and Partigen plates (Hoechst) respectively. $\mathrm{C} 1$ esterase inhibitor (Cĩ INH) and $\mathrm{C} 3 \mathrm{~b}$ inactivator (C3bINA or KAF) were determined by rocket immunoelectrophoresis into barbital buffered agarose $(0.075 \mathrm{M}, \mathrm{pH} 8.6)$ containing specific antisera (Hoechst \& Flow Laboratories). $\beta_{1 \mathrm{H}}$ determinations were performed by single radial immunodiffusion into barbital buffer agarose containing monospecific antiserum to $\beta_{1 \mathrm{H}} \cdot{ }^{11}$ All concentrations, except C3bINA, were determined in absolute terms $(\mathrm{mg} / \mathrm{l})$ by reference to serial dilutions of known standards (Protein Standard Serum and Plasma, Hoechst). C3bINA concentrations were determined in reference to a pool of sera from 25 normal control subjects ( $\% \mathrm{NP})$. 
IMMUNOCONGLUTININS

Immunoglutinins were detected by the method of Lachmann and Hobart. ${ }^{12}$ All sera under test were first decomplemented by heat inactivation at $56^{\circ} \mathrm{C}$ for 30 minutes and then absorbed with half their volume of sheep erythrocytes. Serial dilutions were then made and $0.05 \mathrm{ml}$ of each placed in plastic agglutination trays. To each well was added $0.05 \mathrm{ml}$ of a $1 \%$ suspension of EAC43 antrypol (human) reagent and the cells allowed to settle at $4^{\circ} \mathrm{C}$. EA cells were used as a negative control and rabbit antiserum to human $\mathrm{C} 3$ and $\mathrm{C} 4$ as a positive reaction. A positive immunoconglutinin titre was taken as greater than $1: 4$ under these conditions.

\section{STATISTICS}

All data except that for the immunoconglutinins (1K) were subjected to analysis of variance. $1 \mathrm{~K}$ data were analysed using the McNemar test for significance of change.

\section{Results}

The serum concentrations of CīINH, C3bINA, and $\beta_{1 \mathrm{H}}$ are shown in Figs. 1-3. Tables 1 and 2 give the mean concentrations for these inhibitors and for $\mathrm{C} 3$ and properdin factor $B$. The Tables also give the mean values of patients in remission and for those

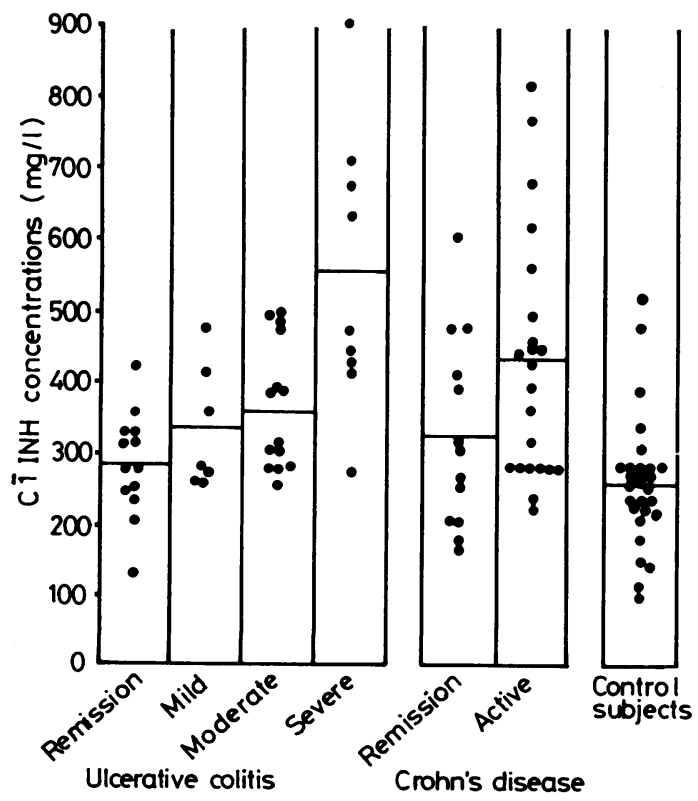

Fig. 1 Serum concentrations of $C \overline{I I N H}$ in control subjects and in patients with inflammatory bowel disease.

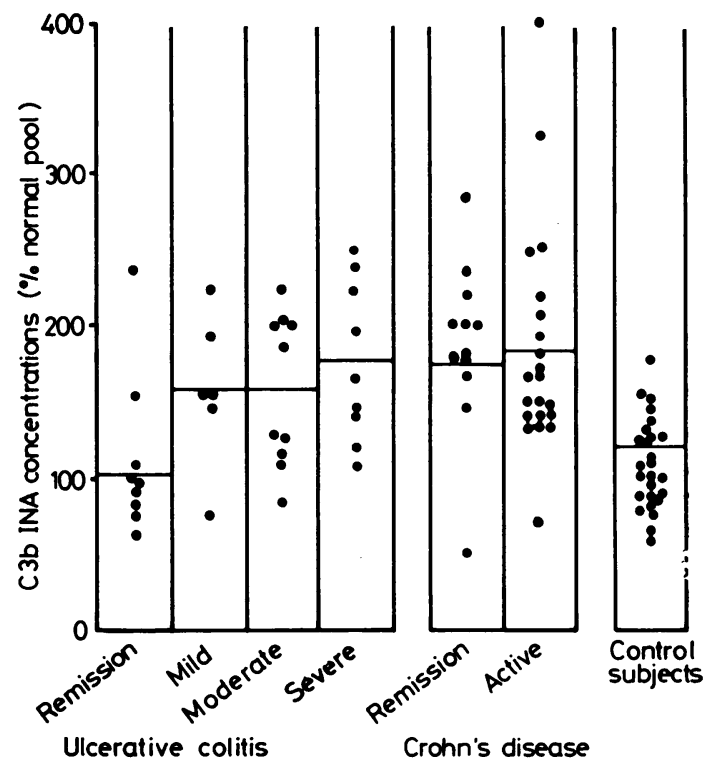

Fig. 2 Serum concentrations of C3bINA in control subjects and in patients with inflammatory bowel disease.

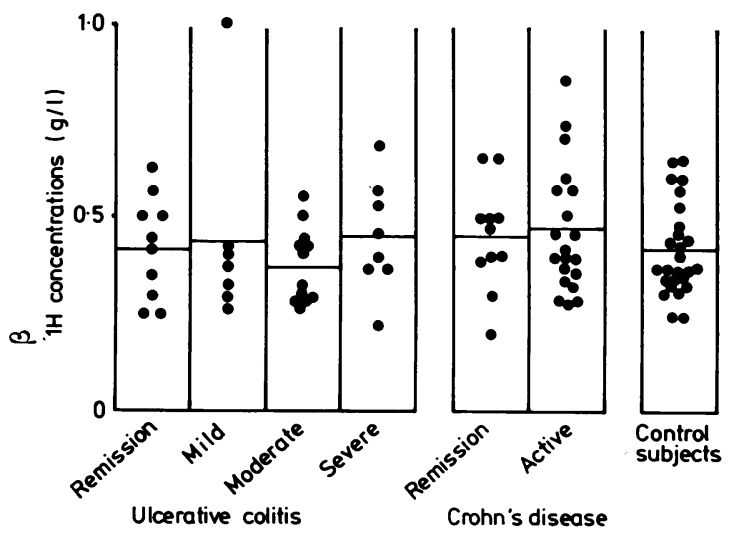

Fig. 3 Serum concentrations of $\beta_{1} \mathrm{H}$ in control subjects and in patients with inflammatory bowel disease.

with active disease. Table 3 contains the immunoconglutinin data for these patients in relation to disease activity and Table 4 the same data in relation to disease history.

Cín In

Serum CīINH concentrations were raised both in the group of patients with ulcerative colitis and those with Crohn's disease $(P<0 \cdot 01)$. The mean values for patients with active disease was significantly higher than for those in remission $(P<0.01)$. 
Table 1 Serum concentrations* of complement components and inhibitors in patients with ulcerative colitis

\begin{tabular}{|c|c|c|c|c|c|c|c|c|}
\hline \multirow[t]{2}{*}{ Group } & \multirow{2}{*}{$\begin{array}{l}\text { Patients } \\
\text { (no.) }\end{array}$} & \multirow{2}{*}{$\begin{array}{l}C 3 \\
(g / l)\end{array}$} & \multirow{2}{*}{$\begin{array}{c}\text { Factor } B \\
(m g / l)\end{array}$} & \multirow{2}{*}{$\begin{array}{l}C \overline{1} I N H \\
(m g / l)\end{array}$} & \multicolumn{2}{|c|}{$C 3 b I N A$} & \multicolumn{2}{|c|}{$\beta_{1 \mathrm{H}}$} \\
\hline & & & & & (no & $(\% N P)$ & (no & $(m g / l)$ \\
\hline $\begin{array}{l}\text { All patients } \\
\text { Remission } \\
\text { Mild } \\
\text { Moderate } \\
\text { Severe } \\
\text { Control subjects } \\
\text { Significance }\end{array}$ & $\begin{array}{r}42 \\
13 \\
7 \\
13 \\
9 \\
28\end{array}$ & $\begin{array}{l}1.45 \pm 0.08 \\
1.07 \pm 0.10 \\
1.63 \pm 0.22 \\
1.36 \pm 0.14 \\
1.98 \pm 0.13 \\
1 \cdot 16 \pm 0.06 \\
P<0.01\end{array}$ & $\begin{array}{l}241 \pm 15 \\
180 \pm 13 \\
234 \pm 47 \\
260 \pm 23 \\
309 \pm 28 \\
168 \pm 10 \\
P<0.01\end{array}$ & $\begin{array}{l}373 \pm 24 \\
286 \pm 20 \\
332 \pm 32 \\
358 \pm 24 \\
553 \pm 20 \\
261 \pm 18 \\
P<0.01\end{array}$ & $\begin{array}{r}35 \\
10 \\
6 \\
10 \\
26\end{array}$ & $\begin{array}{l}147 \pm 9 \\
102 \pm 18 \\
158 \pm 20 \\
158 \pm 16 \\
176 \pm 17 \\
108 \pm 6 \\
P<0 \cdot 01\end{array}$ & $\begin{array}{r}37 \\
10 \\
\\
12 \\
8 \\
26\end{array}$ & $\begin{array}{l}414 \pm 23 \\
419 \pm 41 \\
420 \pm 10 \\
370 \pm 27 \\
450 \pm 50 \\
417 \pm 23 \\
N S\end{array}$ \\
\hline
\end{tabular}

*Mean \pm SEM

Table 2 Serum concentrations* of complement components and inhibitors in patients with Crohn's disease

\begin{tabular}{|c|c|c|c|c|c|c|c|c|}
\hline \multirow[t]{2}{*}{ Group } & \multirow{2}{*}{$\begin{array}{l}\text { Patients } \\
\text { (no.) }\end{array}$} & \multirow{2}{*}{$\begin{array}{l}C 3 \\
(g / l)\end{array}$} & \multirow{2}{*}{$\begin{array}{l}\text { Factor } B \\
(m g / l)\end{array}$} & \multirow{2}{*}{$\begin{array}{l}\bar{C} \overline{I N H} \\
(\mathrm{mg} / l)\end{array}$} & \multicolumn{2}{|c|}{$C 3 b I N A$} & \multicolumn{2}{|c|}{$\beta_{1 H}$} \\
\hline & & & & & $\overline{\text { (no }}$ & $(\% N P)$ & (no & $(m g / l)$ \\
\hline
\end{tabular}

*Mean \pm SEM.

Table 3 Immunoconglutinin titres

\begin{tabular}{ccccccccc}
\hline & 0 & $1 / 4$ & $1 / 8$ & $1 / 16$ & $1 / 32$ & $1 / 64$ & $1 / 128$ & $1 / 256$ \\
\hline $\begin{array}{c}\text { Ulcerative } \\
\text { colitis } \\
n=45\end{array}$ & 29 & 3 & 5 & 2 & 3 & 1 & 1 & 1 \\
$\begin{array}{c}n=45 \\
\text { disease } \\
n=41 \\
\begin{array}{c}n=4 \\
n=32\end{array}\end{array}$ & 29 & 3 & 0 & 2 & 1 & 3 & 3 & 1 \\
\hline
\end{tabular}

Table 4 Immunoconglutinins in inflammatory bowel disease and control subjects

\begin{tabular}{lll}
\hline Group & $n$ & $\begin{array}{l}\% \text { IK Positive } \\
(\text { titre }>1: 4)\end{array}$ \\
\hline Ulcerative colitis & 45 & 38 \\
Active & 28 & 43 \\
Remission & 17 & 29 \\
Crohn's disease & 41 & 29 \\
Active & 27 & 37 \\
Remission & 14 & 14 \\
Controls & 32 & 25 \\
\hline
\end{tabular}

From Fig. 1 it will be seen that, for patients with ulcerative colitis, the mean values increased with increasing severity of the disease.

\section{C3 bina}

The mean serum levels for C3bINA were increased in all patients with inflammatory bowel disease $(P<0.01)$. In patients with ulcerative colitis those with active disease had significantly higher serum concentrations and the mean values correlated with disease activity, whereas those in remission tended towards normal values. No such distinction could be made between active and inactive disease in patients with Crohn's disease.

$\beta_{1 H}$

All except two values were within the normal range for this protein. There was no significant difference between the patients with inflammatory bowel disease and the control subjects.

\section{CORRELATIONS BETWEEN SERUM}

CONCENTRATIONS

There was no general correlation with any two serum components and inhibitors measured over the entire group of subjects. However, C3bINA did correlate with C3 in Crohn's disease $(r=0.418, P<0.01)$ and with factor $B$ in ulcerative colitis $(r=0.527, P<0.01)$, and control subjects $(r=0 \cdot 169, \mathrm{P}<0.01)$.

\section{IMMUNOCONGLUTININS}

The titres obtained in each group are shown in Table 3. In both ulcerative colitis and Crohn's disease there was a greater incidence of positive $1 \mathrm{~K}$ titres $(>1: 4)$ in active disease than in the control subjects $(\mathrm{P}<0.01)$. The incidence in remission, however, was within the normal range (Table 4). When patients were examined for positive $1 \mathrm{~K}$ titres in relationship to disease history, it was found that both groups showed a similar pattern and are therefore grouped together in Table 5. From this 
Table 5 Disease history and immunoconglutinin titre in inflammatory bowel disease

\begin{tabular}{llll}
\hline Patients & 1st attack & 5 years & -5 years \\
\hline No. & 18 & 43 & 25 \\
$\%$ IK positive & 17 & 35 & 44 \\
(Controls $25 \%$ & IK positive) & & \\
\hline
\end{tabular}

Table it can be seen that the incidence of positive $1 \mathrm{~K}$ titres increases significantly with length of history. Seventeen per cent of patients during their first attack had a positive $1 \mathrm{~K}$ titre and this rose to $44 \%$ in patients who had had their disease longer than five years. This increase of $1 \mathrm{~K}$ titres in patients with long-standing disease was independent of disease activity.

\section{Discussion}

Immune complexes have been found in the sera of patients with ulcerative colitis and Crohn's disease by a variety of methods. ${ }^{813-15}$ Earlier workers, using an indirect test, have reported the presence of endotoxin in these patients. ${ }^{16}$ Complement may, therefore, be activated by both classical and alternative pathways. Many workers have found alterations in the serum concentration of classical pathway components ${ }^{134}$ and in factor $\mathrm{B}^{2}$. We have previously shown that there is increased catabolism of $\mathrm{Cl}_{\mathrm{q}},{ }^{5}$ a classical pathway component, and of $\mathrm{C} 3,{ }^{6}$ which is common to both pathways in patients whose serum concentrations of these components were raised. What was not apparent from these earlier studies was whether increased activation was due to antigen-antibody reactions and/or endotoxin, or whether it resulted from a failure to modulate the system.

The present study has shown that the concentrations of CĩINH and C3bINA, modulators of the classical and alternative pathways respectively, rise during a relapse of ulcerative colitis and return to normal levels as the disease goes into remission. A similar pattern was seen for Cî̃NH in patients with Crohn's disease but no such change occurred for C3bINA. The concentrations of $\beta_{1 \mathrm{H}}$, another modulator of the alternative pathway, were within the normal range in both diseases and showed no change with disease activity. This is in agreement with the finding of Charlesworth et al. ${ }^{11}$ who found that ${ }_{1 \mathrm{H}}$ did not behave as an acute phase reactant when compared with C-reactive protein.

However, functional activity of these complement modulators cannot be deduced from serum concentrations. Similarly, serum concentrations provide no information of the catabolism of these proteins. Studies of functional activity and catabolism are required to elucidate the effectiveness of the control of the complement system. A functional abnormality in the alternative pathway in inflammatory bowel disease has been suggested by the diminished activation by cobra venom factor (CoVF). ${ }^{4}$ Serum properdin and properdin convertase activity are also diminished. ${ }^{4}$ These changes are not specific for inflammatory bowel disease, as diminished activation by CoVF has been reported in other situations $^{17}{ }^{18}$ and similar changes in properdin have been found in systemic lupus erythematosus, ${ }^{19}$ membranoproliferative glomerulonephritis, ${ }^{20}$ and in association with endotoxin..$^{21}$

Initial observations by Pepys and co-workers ${ }^{22}$ showed a $41 \%$ incidence of positive $1 \mathrm{~K}$ titres in patients with inflammatory bowel disease, an incidence similar to that reported in the present study. It has now been shown that the height of the titre correlates positively with the duration of the disease which strongly suggests that there is continuing complement activation in these patients. There is some controversy, however, over the presence of C3 conversion products in these patients. Teisberg and Gjone $^{7}$ have shown $\mathrm{C} 3$ activation products in the sera of many of these patients, but they are rarely found if plasma is used. ${ }^{2-2} \mathrm{C} 3$ has been observed as deposits in the intestinal wall by some ${ }^{2324}$ but not by others. ${ }^{25}$

The results of this study, therefore, provide additional evidence compatible with the view that complement activation is a factor in the pathogenesis of mucosal inflammation in ulcerative colitis and Crohn's disease. There is no quantitative deficiency in the modulators and inhibitors of the complement system and more sophisticated studies are now required to assess their functional activity.

The authors would like to thank Dr B Pussell, Royal Postgraduate Medical School, for determining the $\beta_{1 \mathrm{H}}$ serum concentrations.

\section{References}

${ }^{1}$ Hodgson HJF, Potter BJ, Jewell DP. Humoral immune system in inflammatory bowel disease: 1 Complement levels. Gut 1977; 18: 749-53.

${ }^{2}$ Feinstein PA, Kaplan SR, Thayer WR Jnr. The alternate complement pathway in inflammatory bowel disease. Quantitation of the C3 proactivator (factor B) protein. Gastroenterology 1976; 70: 181-5.

${ }^{3}$ Ward M, Eastwood MA. Serum complement components $\mathrm{C} 3$ and $\mathrm{C} 4$ in inflammatory bowel disease (Abstract). Gut 1974; 15: 835 .

${ }^{4}$ Lake AM, Stitzel AE, Urmson JR, Walker WA, Spitzer RE. Complement alterations in inflammatory bowel disease. Gastroenterology 1979; 76: 1374-9. 
${ }^{5}$ Potter BJ, Hodgson HJF, Mee AS, Jewell DP. Clq metabolism in ulcerative colitis and Crohn's disease. Gut 1979; 20: 1012-9.

${ }^{6}$ Hodgson HJF, Potter BJ, Jewell DP. C3 metabolism in ulcerative colitis and Crohn's disease. Clin exp Immunol 1977; 28 : 490-5.

7Teisberg P, Gjone E. Humoral immune system activity in inflammatory bowel disease. Scand $J$ Gastroenterol 1975; 10 : 545-9.

${ }^{8}$ Nielsen H, Binder V, Daugharty H, Svehag SE. Circulating immune complexes in ulcerative colitis. I. Correlation to disease activity. Clin exp Immunol 1978; 31: 72-80.

${ }^{9}$ Truelove SC, Witts LJ. Cortisone in ulcerative colitis: final report on a therapeutic trial. $B r M e d J 1955$; 2: 1041-8.

${ }^{10}$ de Dombal FT, Burton IL, Clamp SE, Goligher JC. Short-term course and prognosis of Crohn's disease. Gut 1974; 15: 435-43.

${ }^{11}$ Charlesworth JA, Scott DM, Pussell BA, Peters DK. Metabolism of B1H: studies in man and experimental animals. Clin Exp Immunol 1979; 38: 397-404.

${ }^{12}$ Lachmann PJ, Hobart MJ. Complement technology pp 5A1-5A23, In: Weir DM, ed., Handbook of experimental immunology, vol 1, Oxford: Blackwell, 1978.

${ }^{13}$ Jewell DP, MacLennan ICM. Circulating immune complexes in inflammatory bowel disease. Clin Exp Immunol 1973; 14: 219-26.

${ }^{14}$ Doe WF, Booth CC, Brown DL. Evidence for complement binding immune complexes in adult coeliac disease, Crohn's disease and ulcerative colitis. Lancet 1973; 1: 402-3.

${ }^{15}$ Hodgson HJF, Potter BJ, Jewell DP. Immune complexes in ulcerative colitis and Crohn's disease. Clin Exp Immunol 1977; 29: 187-96.
${ }^{16}$ Bowen GE, Kirsner JB. Positive epinephrine skin test for 'circulating endotoxin' in inflammatory disease of the intestine. Am J Clin Pathol 1965; 44: 642-7.

${ }^{17}$ Kalwinsky DK, Urmson KR, Stitzel AE, Spitzel RE. Activation of the alternative pathway of complement in childhood acute lymphoblastic leukemia. J Lab Clin Med 1976; 88: 745-56.

${ }^{18}$ Adamkin D, Stitzel A, Urmson J, Farnett ML, Post E, Spitzer R. Activity of the alternative pathway of complement in the newborn. J Pediatr 1978; 93: 604-8.

${ }^{19}$ Kohler PF ten Bensel R. Serial complement component: alterations in acute glomerulonephritis and systemic lupus erythematosis. Clin Exp Immunol 1969; 4: 191-202.

${ }^{20}$ Gewurz H, Pickering RJ, Naff G, Snyderman R, Mergenhagen SE, Good, RA. Decreased properdin activity in acute glomerulonephritis. Int Arch Allergy Appl Immunol 1969; 36: 592-8.

${ }^{21}$ Gerwurz H, Shin HS, Mergenhagen SE. Interactions of the complement system with endotoxin lipopolysaccharide: consumption of each of the six terminal complement components. J Exp Med 1968; 128: 1049-57.

${ }^{22}$ Pepys MB, Druguet M, Klass HJ, Dash AC, Mirjah DD. Petrie A. Immunological studies in inflammatory bowel disease. In: Immunology of the Gut, Ciba Foundation Symposium 46 (new series) North Holland: Elsevier Excerpta Medica, 1977; 283-304.

${ }^{23}$ Ballard J, Shiner M. Evidence of cytotoxicity in ulcerative colitis from immunofluorescent staining of the rectal mucosa. Lancet 1974; 1 : 1014-7.

${ }^{24}$ Gebbers JO, Otto HF. Evidence for local immune complexes in ulcerative colitis. Acta Gastroenterol Belg 1978; 41 : 329-59.

${ }^{25}$ Baklien K, Brandtzaeg P. Comparative mapping of the local distribution of immunoglobulin containing cells in ulcerative colitis and Crohn's disease. Clin Exp Immunol 1975; 22 : 197. 